\title{
Structure of Tryptoquivaline C (FTC) and D (FTD). Novel Fungal Metabolites from Aspergillus fumigatus ${ }^{1)}$
}

\author{
Mikio Yamazaki, Haruhiro Fujimoto, and Emi Okuyama \\ Research Institute for Chemobiodynamics, Chiba University ${ }^{2}$
}

(Received February 7, 1977)

\begin{abstract}
Structures of tryptoquivaline $\mathrm{C}$ and $\mathrm{D}$, isolated from Aspergillus fumigatus were determined as I and II. The stereostructure of $I$ was determined by direct comparison of I with tryptoquivaline which structure was determined by $\mathrm{X}$-ray analysis already. Stereostructure of II was determined by comparison of its spectral data with that of I and from the result that compound A (VIa or b) was obtained on oxidation of both I and II. Since L- $(+)$-alanine was obtained by hydrolysis of a reduction product from II, S-configuration was proposed on the stereochemistry of C-15 in II.
\end{abstract}

Keywords_-structure determination; fungal metabolite; tryptoquivaline $\mathrm{C}$; tryptoquivaline D; Aspergillus fumigatus

Ten unknown metabolites, tentatively designated as fumigatus toxin A-J (FTA-J), were isolated in our laboratory from Aspergillus fumigatus found growing on rice grains. Two (FTA and B) among them were strongly tremorgenic and named fumitremorgin $\mathrm{A}$ and B. The chemical structures of these two compounds were elucidated as prenylated 2,5-dioxopiperazine consisted of 6-methoxytryptophan and proline. ${ }^{3)}$ Eight metabolites remaining (FTC-J) were not strongly tremorgenic and differed somewhat from FTA and B in their physicochemical properties. In this paper, the structure elucidation on FTC and D is described.

FTC (I), $\mathrm{C}_{29} \mathrm{H}_{30} \mathrm{~N}_{4} \mathrm{O}_{7}, \operatorname{mp} 215-217^{\circ}$ (dec.), $[\alpha]_{D}+168^{\circ}$, and D (II), $\mathrm{C}_{28} \mathrm{H}_{28} \mathrm{~N}_{4} \mathrm{O}_{7}, \mathrm{mp} 224-$ $225^{\circ}$ (dec.), $[\alpha]_{\mathrm{D}}+115^{\circ}$, were isolated from ethyl acetate extract of the fungus cultured on

isolation of FTA-J

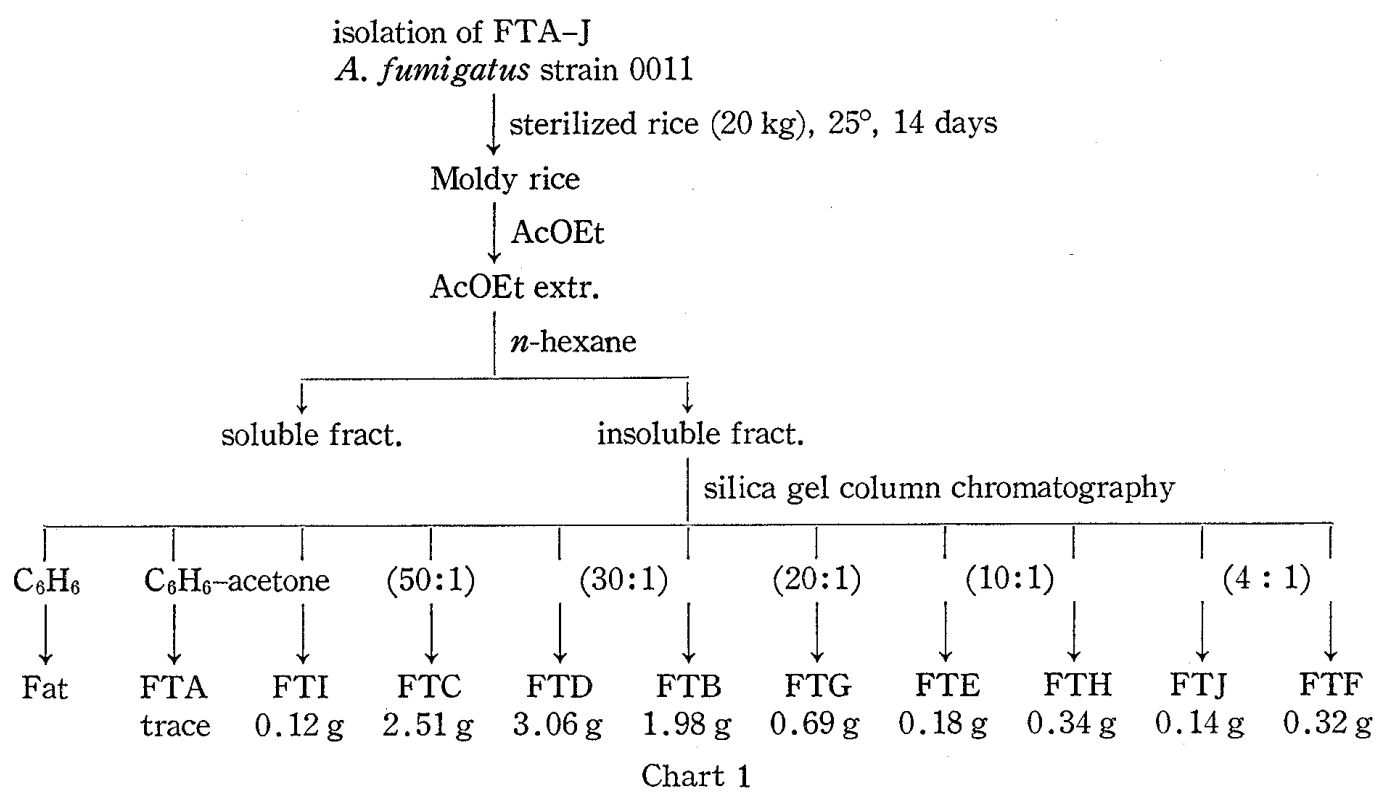

1) A part of this study was preliminary reported by M. Yamazaki, H. Fujimoto, and E. Okuyama in Tetrahedron Lett., 1976, 2861.

2) Location: 3-9-1, Izumicho, Narashino, Chiba, 275, Japan.

3) M. Yamazaki, H. Fujimoto, and T. Kawasaki, Tetrahedron Lett., 1975, 1241, and references cited therein. 
rice grains through silica gel column chromatography together with fumitremorgin $\mathrm{A}$ and $\mathrm{B}$ and FTE- $\mathrm{J}$ as shown in Chart 1.

Physico-chemical properties of FTC and D were very similar with each other as shown in Table I.

TABLe I. Physico-Chemical Properties of FTC and FTD

\begin{tabular}{|c|c|c|}
\hline & FTC (I) & FTD (II) \\
\hline $\mathrm{mp}$ & $215-217^{\circ}(\mathrm{dec})$. & $224-225^{\circ}($ dec. $)$ \\
\hline & $\begin{array}{l}\mathrm{C}_{29} \mathrm{H}_{30} \mathrm{~N}_{4} \mathrm{O}_{7}\left(\mathrm{M}^{+}: m / e \mathrm{e}^{5} 6\right) \\
+168^{\circ}\left(\mathrm{CHCl}_{3}\right)\end{array}$ & $\begin{array}{l}\mathrm{C}_{28} \mathrm{H}_{28} \mathrm{~N}_{4} \mathrm{O}_{7}\left(\mathrm{M}^{+}: m / e 532\right) \\
+115^{\circ}\left(\mathrm{CHCl}_{3}\right)\end{array}$ \\
\hline$\lambda_{\max }^{\mathrm{MeOH}} \mathrm{nm}(\varepsilon)$ & $\begin{array}{l}228(39800), 233 \text { (sh., 38000), 255(sh., } \\
21100), 280 \text { (sh., 14200), 307(sh., } \\
\text { 4200), 320(sh., 2700). }\end{array}$ & $\begin{array}{l}227(48100), 233 \text { (sh., } 45200), 257 \text { (sh., } \\
21500), 277 \text { (sh., } 14500), 305 \text { (sh., } \\
4800), 319 \text { (sh., } 3300) \text {. }\end{array}$ \\
\hline $\begin{array}{l}\nu_{\max }^{\mathrm{KBr}} \mathrm{cm}^{-1} \\
\operatorname{PMR} \delta(\mathrm{ppm})\end{array}$ & $\begin{array}{l}3490,1760,1745(\mathrm{sh} .), 1665,1600 . \\
1.04(3 \mathrm{H}, \mathrm{d} ., 6), 1.14(3 \mathrm{H}, \text { d., } 6), \\
1.48(3 \mathrm{H}, \mathrm{s} .), 1.50(3 \mathrm{H}, \mathrm{s} .), 2.17 \\
(3 \mathrm{H}, \mathrm{s} .), 3.03(1 \mathrm{H}, \mathrm{d} . \mathrm{d} ., 14,10), 3.20 \\
(1 \mathrm{H}, \mathrm{d} . \mathrm{d} ., 14,10), 2.67(1 \mathrm{H}, \mathrm{m}), \\
4.99(1 \mathrm{H}, \mathrm{s} .), 5.59(1 \mathrm{H}, \mathrm{d} ., 9), 5.67 \\
(1 \mathrm{H}, \mathrm{t} ., 10), 7.33-7.93(7 \mathrm{H}, \mathrm{m} .), \\
8.22(1 \mathrm{H}, \mathrm{d} ., 8), 7.08(1 \mathrm{H}, \mathrm{s} ., \text { disap- } \\
\text { peared with } \mathrm{D}_{2} \mathrm{O} \text { addition). }\end{array}$ & $\begin{array}{l}3430,1778,1732,1660,1610 . \\
0.97(3 \mathrm{H}, \text { d., } 7), 1.09(3 \mathrm{H}, \text { d., } 7), \\
1.56(3 \mathrm{H}, \text { d., } 7), 2.14(3 \mathrm{H}, \mathrm{s}), 2.93 \\
(1 \mathrm{H}, \text { d. d., } 14,9), 3.19(1 \mathrm{H}, \text { d. d., } 14, \\
9), 2.57(1 \mathrm{H}, \mathrm{m} .), 4.32(1 \mathrm{H}, \mathrm{q} ., 7), \\
5.10(1 \mathrm{H}, \mathrm{s}), 5.61(1 \mathrm{H}, \mathrm{d} ., 8), 5.74 \\
(1 \mathrm{H}, \mathrm{t}, 9), 7.11-7.99(7 \mathrm{H}, \mathrm{m} .), 8.24 \\
(1 \mathrm{H}, \mathrm{d} ., 8), 7.26(1 \mathrm{H}, \text { s., disappeared } \\
\left.\text { with } \mathrm{D}_{2} \mathrm{O} \text { addition }\right) \text {. }\end{array}$ \\
\hline
\end{tabular}

UV and IR, sh.: shoulder.

PMR, Coupling pattern and/or coupling constant $(\mathrm{Hz})$ of signals are shown in parentheses. s.:singlet, d.: doublet, d.d.: doublets of doublet, t.: triplet, q.:quartet, m.:multiplet.

Tryptophan- $3-{ }^{14} \mathrm{C}$ added to the culture medium was actually incorporated into FTC as well as into FTA, suggesting that FTC contained tryptophan moiety in its structure. ${ }^{4}$. From the ultraviolet absorption (UV) spectra of these compounds, the presence of the quinazolone ring in their molecules in addition to the indole related structure was indicated. ${ }^{5}$ ) The infrared abosrption (IR) spectra of FTC and D showed the presence of carbonyl groups of $\gamma$-lactone, ester and amide along with hydroxyl group in their molecules. FTC and D were both insoluble in $1 \mathrm{~N} \mathrm{HCl}$ and $1 \mathrm{~N} \mathrm{NaOH}$ and were negative to $p$-dimethylaminobenzaldehyde (Ehrlich) and ferric chloride test reagents. From the result in the proton magnetic resonance (PMR) spectrometry, the presence of $\mathrm{CH}_{3}^{\mathrm{CH}_{3}}>\mathrm{CH}-\mathrm{CH}-$ and $-\mathrm{CH}_{2}-\mathrm{CH}-$, two tertiary methyls, one methine, one acetyl methyl, eight aromatic hydrogens and one hydroxyl (disappeared with $\mathrm{D}_{2} \mathrm{O}$ ) in the structure of FTC was indicated. FTC afforded an acetate (III), $\mathrm{C}_{31} \mathrm{H}_{32} \mathrm{~N}_{4} \mathrm{O}_{8}$, $\mathrm{mp} 194-195^{\circ},[\alpha]_{\mathrm{D}}+132^{\circ}$, by acetylation with acetic anhydride in pyridine, indicating also the presence of hydroxyl group in FTC. Reflux of FTC in methanolic alkali solution produced a desacetyl compound which showed levo-rotatory optical activity. This compound was reacetylated with acetic anhydride in pyridine to give an acetate (IV), $\mathrm{C}_{31} \mathrm{H}_{32} \mathrm{~N}_{4} \mathrm{O}_{8}, \mathrm{mp} 144-146^{\circ}$, $[\alpha]_{\mathrm{D}}-199^{\circ}$.

The UV and IR spectral data of III and IV were similar with each other except that their optical rotations were opposite. A negative curve was observed in the optical rotatory dispersion (ORD) spectrometry of IV in contrast to that of III which showed a positive curve. In the PMR spectrum of IV, a signal of one hydrogen of methylene in $-\mathrm{CH}_{2}-\mathrm{CH}-(\mathrm{ABX}-$ type) structure was observed shifted to the higher field about $0.3 \mathrm{ppm}$ compared with that in III. Accordingly, it was estimated that III and IV were stereoisomeric with each other and FTC was probably epimerized with alkali during deacetylation reaction.

4) M. Yamazaki, K. Sasago, and K. Miyaki, 17th Annual Meeting of Kanto Branch, Pharmaceutical Society of Japan (Tokyo, 1973).

5) A.W. Sangster and K.L. Stuart, Chem. Rev., 65, 69 (1965). 
The difference between FTC and D in their molecular formulae was $\mathrm{CH}_{2}$. In the PMR spectrum of FTD, a doublet of methyl group appeared at $1.56 \mathrm{ppm}$ along with a quartet of one hydrogen at $4.32 \mathrm{ppm}$ nevertheless two singlet methyls were observed at 1.48 and $1.50 \mathrm{ppm}$ without quartet hydrogen in that of FTC. This result indicated that FTD was devoid of one methyl group in its structure in spite of two tertiary methyl groups were present in FTC. FTD was not acetylated in a same way to that in FTC, however FTD afforded an acetate (V), $\mathrm{C}_{30} \mathrm{H}_{30} \mathrm{~N}_{4} \mathrm{O}_{8} \cdot 1 / 2 \mathrm{H}_{2} \mathrm{O}, \mathrm{mp} 185-186^{\circ}$, by standing it overnight in a mixture of acetic anhydride and acetic acid.

Oxidation of FTC with chromium trioxide in $90 \%$ acetic acid gave two main products, compound $\mathrm{A}$ (VI) and $\mathrm{B}$ (VII). Compound $\mathrm{A}, \mathrm{C}_{25} \mathrm{H}_{23} \mathrm{~N}_{3} \mathrm{O}_{6}$, colorless needles, $\mathrm{mp} 160-162^{\circ}$, showed the absorption maxima at 280, 307 and $318 \mathrm{~nm}$ in the UV spectrum, indicating that this compound probably contained the quinazolone ring similarly to FTC and D. ${ }^{5)}$ In the PMR spectrum of compound $\mathrm{A}$, the signals corresponding to $\mathrm{CH}_{3}>\mathrm{CH}-\mathrm{CH}-,-\mathrm{CH}_{2}-\mathrm{CH}-$, $\mathrm{CH}_{3} \mathrm{CO}$ and eight aromatic hydrogens were observed along with that of $\mathrm{NH}$ group. The chemical shifts of these signals were almost common to those of FTC and D except that of $\mathrm{NH}$ appeared at $9.07 \mathrm{ppm}$ (disappeared with $\mathrm{D}_{2} \mathrm{O}$ ). The IR spectral data suggested the presence of four carbonyl groups in this compound.

Compound $\mathrm{A}$ was received acetylation with acetic anhydride in pyridine to give acetate (VIII), mp 134-137. . From the various spectral data obtained above, the carbon skeleton of this compound was estimated as having a combined structure of the quinazolone ${ }^{5)}$ and oxindole ${ }^{6)}$ rings together with such systems as $\mathrm{CH}_{3}^{\mathrm{CH}_{3}}>\mathrm{CH}-\mathrm{CH}$ - and $-\mathrm{CH}_{2}-\mathrm{CH}-$. Since the characteristic absorption bands in $390-420 \mathrm{~nm}$ for $\phi$-indoxyl chromophore ${ }^{7)}$ was not observed, the possibility that $\psi$-indoxyl group instead of oxindole would be present in compound A was excluded. Possible structure of compound A was thus given as shown as (VIa) or (VIb).

Compound $\mathrm{B}$ (VII), $\mathrm{C}_{29} \mathrm{H}_{28} \mathrm{~N}_{4} \mathrm{O}_{9}, \mathrm{mp} 207-208.5^{\circ}$, was obtained on oxidation of FTC with chromium trioxide in $90 \%$ acetic acid but not obtained from FTD in a same manner. On oxidation of FTC with chromium trioxide in pyridine, on the other hand, compound A was obtained but compound B was not obtained. On the chemical structure of compound B, no detail study was yet carried out.

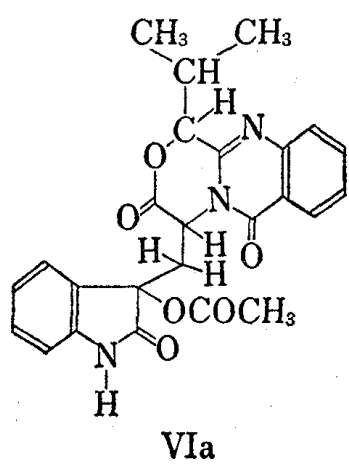

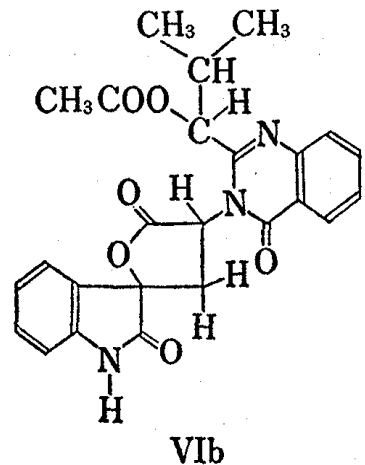

Fig. 1. Presumed Structure of Compound A $\mathrm{VIa}$ or $\mathrm{VIb}$ )

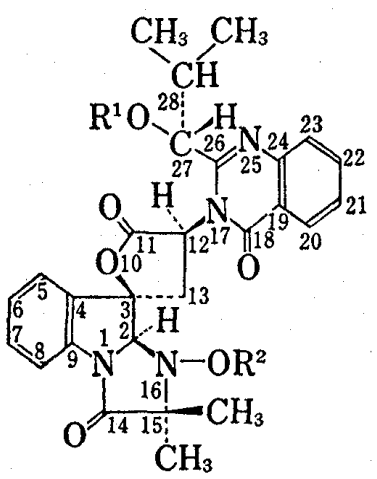

tryptoquivaline

$\left(\mathrm{R}^{1}: \mathrm{COCH}_{3}, \mathrm{R}^{2}: \mathrm{H}\right)(\mathrm{IX})$ tryptoquivaline $\mathrm{C}$ (FTC) (I)

(R': H, R ${ }^{2}: \mathrm{COCH}_{3}$ )

Fig. 2. Structures of Tryptoquivaline C (FTC) and D (FTD)

6) S. Sakai, N. Aimi, K. Yamaguchi, H. Ohhira, K. Hori, and H. Haginiwa, Tetrahedron Lett., 1975, 715; Lilly Research Laboratories, Physical data of indole and dihydroindole alkaloids $(1960,1962,1964)$.

7) B. Witkop and J.B. Patrick, J. Am.Chem. Soc., 73, 2188 (1951) ; N. Finch, W.I. Taylor, and P.R. Ulshafer, Experientia, 19, 296 (1963); A.J. Birch and J.J. Wright, Tetrahedron, 26, 2329 (1970). 
During our study on the structure elucidation on FTC and D was under way, Clardy, et al. isolated tryptoquivaline (IX) and tryptoquivalone from a fungus, Aspergillus clavatus and they determined the structure of tryptoquivaline by X-ray analysis. ${ }^{8}$ The properties of IX reported therein by Clardy, et al. suggested the close similarity of this metabolite to our FTC although these compounds were not entirely identical with each other. The fact lead us to try comparison of FTC and IX, and result of the direct comparison of FTC acetate (III) with acetate of IX showed their complete identity. Thus the chemical structure of FTC including the stereochemistry was proposed as I, an isomer of tryptoquivaline regarding the position of an acetyl group.

FTD could therefore be shown as II, and its stereostructure in common to that of FTC was estimated from the result of the oxidation reaction on which both FTC and D gave compound A. Stereochemistry on position 15 in FTD, S-configuration was proposed since L$(+)$-alanine was obtained by hydrolysis of FTD after reduction with zinc in acetic acid (Chart 2).

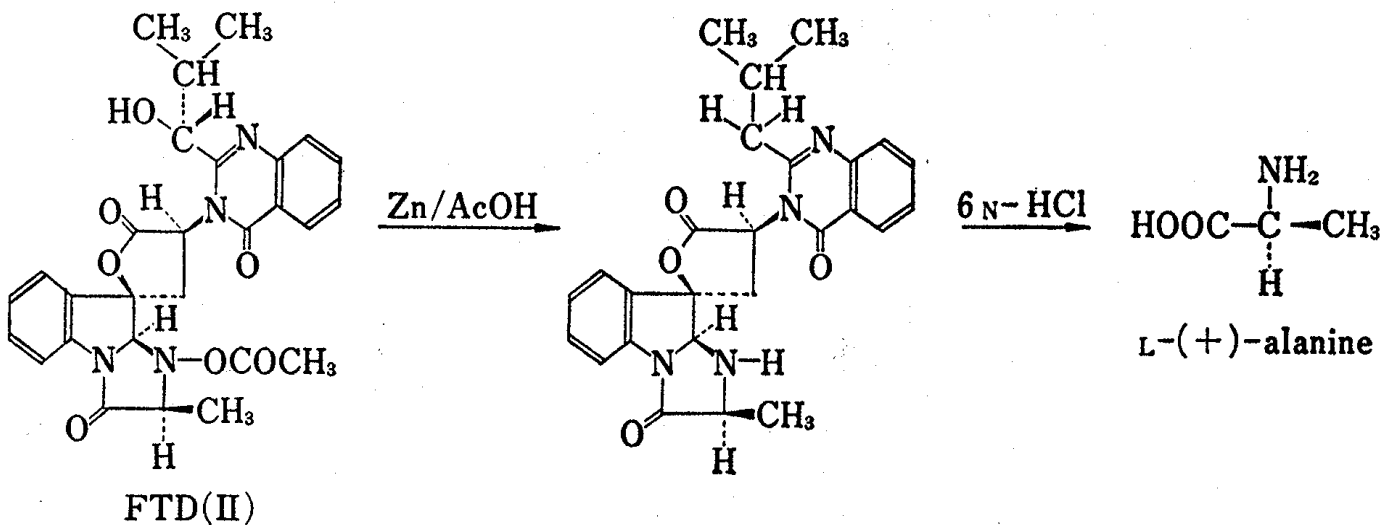

Chart 2

After consideration on the structure of FTC, three hydrogens of ABX-type [3.03 ppm (1H, d.d., $\left.J_{1}=14, J_{2}=10 \mathrm{~Hz}\right), 3.20\left(1 \mathrm{H}\right.$, d.d., $\left.J_{1}=14, J_{2}=10\right)$ and $5.67\left(1 \mathrm{H}, \mathrm{t}\right.$., $J_{1}=$ $\left.\left.J_{2}=10\right)\right]$ observed in the PMR spectra of FTC and D seemed to be corresponding to that of $-\mathrm{CH}_{2}-\mathrm{CH}$ - structure in the spiro- $\gamma$-lactone ring. In the PMR spectrum of compound A, however, the chemical shifts of two hydrogens among these three were obviously differed [2.67 (1H, d.d., $\left.J_{1}=14, J_{2}=9\right), 3.51\left(1 \mathrm{H}\right.$, d.d., $\left.J_{1}=14, J_{2}=9\right)$ and $5.79\left(1 \mathrm{H}\right.$, br.t., $J_{1}=J_{2}=$ 9)] from that of FTC and D, indicating that the spiro- $\gamma$-lactone ring present in FTC and D no longer remained in compound A. Accordingly, VIa was expected to be more suitable structure than VIb for compound $\mathrm{A}$.

Although tryptoquivaline and tryptoquivalone were reported as they have a tremorgenic property, ${ }^{8)}$ FTC and D did not exhibit tremorgenic effect in dose of $0.3 \mathrm{mg} / \mathrm{kg}(i . v$.) to mice in our experiment. On the other hand, fumitremorgin A and B simultaneously obtained from the same fungus exactly exhibited a strong tremorgenic and convulsive effect to mice by administration of similar dose.

The isolation of such a curious type of natural fungal products in Büchi's and our laboratories may be the first example. It is easily supposed that these metabolites are derived from four amino acids such as tryptophan, anthranilic acid, alanine (or methyl alanine) and leucine although the biosynthetic investigation on these metabolites is still under way using radioactive and stable isotopes in our laboratory.

8) J. Clardy, J.P. Springer, G. Büchi, K. Matsuo, and R. Wightman, J. Am. Chem. Soc., 97, 663 (1975). 
We would like to propose newly that tryptoquivaline isolated by Büchi, et al. ${ }^{87}$ is now called as tryptoquivaline A and tryptoquivalone as trytoquivaline B and FTC as tryptoquivaline $C$ and FTD as tryptoquivaline $D$ although we have formerly named FTC and D as isotryptoquivaline and norisotryptoquivaline in our preliminary report.1) The detail on the structure determination of FTE-J will be reported in a following paper and they will be named as tryptoquivaline $\mathrm{E}-\mathrm{J}$.

\section{Experimental}

All melting points were uncorrected. Optical rotations: Yanagimoto Automatic Polarimeter Or-50 (in chloroform). UV: Hitachi Recording Spectrophotometer 323, IR: Hitachi Grating Infrared Spectrophotometer EPI-G3, PMR: Japan Electron Optics Lab. NMR Spectrometer JNM-PS-100 (in deuterochloroform using $\mathrm{Me}_{4} \mathrm{Si}$ as internal standard), Mass: Hitachi Double Focus Mass Spectrometer RMU-6E, and Japan Electron Optics Lab. Double Focus Mass Spectrometer JMS-01SG-2, ORD: Japan Spectroscopic Manufac. Co. ORD/CD Spectropolarimeter J-20. Silica gel, E. Merck Kieselgel G and H nach Stahl, was used for all thin-layer chromatographic analyses. Liquid chromatographic analyses were carried out with Hitachi Liquid Chromatograph Model 034.

Isolation of Metabolites from the Cultured Fungus_-Aspergillus fumigatus Strain 0011 was incubated stationarily on sterilized rice $(20 \mathrm{~kg})$ at $25^{\circ}$ for 14 days. The moldy rice was extracted with EtOAc (24 l) under stirring for $24 \mathrm{hr}$ three times at room temperature.

After evaporation of solvent in vacuo, an extract $(178 \mathrm{~g})$ was obtained as a resinous residue. After defatting with $n$-hexane (2.5 1) under stirring at room temperature, the extract ( $88 \mathrm{~g})$ was chromatographed on silica gel $(1 \mathrm{~kg})$ using $\mathrm{C}_{6} \mathrm{H}_{6}, \mathrm{C}_{6} \mathrm{H}_{6}$-acetone $(50: 1),(30: 1),(20: 1),(10: 1)$, and (4:1) as developing solvents. FTA and FTC were obtained from $\mathrm{C}_{6} \mathrm{H}_{6}$-acetone $(50: 1)$ fraction. Repeated chromatography of $\mathrm{C}_{6} \mathrm{H}_{6}-$ acetone (30:1) fraction on silica gel gave FTD and FTB.

Further six unknown tryptoquivaline-type compounds, (namely tryptoquivaline E, F, G, H, I and J), were separated from the defatted extract on careful chromatography.

FTC (I) was crystallized from $\mathrm{MeOH}$ as colourless needles, $\mathrm{mp} 215-217^{\circ}$ (dec.), $[\alpha]_{\mathrm{D}}^{28}+168^{\circ}(c=0.23)$. Anal. Calcd. for $\mathrm{C}_{29} \mathrm{H}_{30} \mathrm{~N}_{4} \mathrm{O}_{7}(546.2114) \mathrm{C}, 63.72 ; \mathrm{H}, 5.53 ; \mathrm{N}, 10.25$. Found: $\mathrm{C}, 63.82 ; \mathrm{H}, 5.55 ; \mathrm{N}, 10.19$.

FTD (II) was crystallized from $\mathrm{MeOH}$ as colourless needles, $\mathrm{mp} 224-225^{\circ}(\mathrm{dec}),.[\alpha]_{\mathrm{D}}^{28}+115^{\circ}(c=0.23)$. Anal. Calcd. for $\mathrm{C}_{28} \mathrm{H}_{28} \mathrm{~N}_{4} \mathrm{O}_{7}(532.1958) \mathrm{C}, 63.15 ; \mathrm{H}, 5.30 ; \mathrm{N}, 10.52$. Found: $\mathrm{C}, 63.00 ; \mathrm{H}, 5.40 ; \mathrm{N}, 10.33$.

Acetylation of Tryptoquivaline C (FTC) — FTC-acetate (III) $(98 \mathrm{mg}$ ) was obtained by standing a solution of FTC $(109 \mathrm{mg})$ in $\mathrm{Ac}_{2} \mathrm{O}(0.5 \mathrm{ml})$ and pyridine $(1.0 \mathrm{ml})$ at room temperature for $43 \mathrm{hr}$. III was crystallized from $\mathrm{CH}_{2} \mathrm{Cl}_{2}-\mathrm{C}_{6} \mathrm{H}_{6}$ as colourless prisms, $\mathrm{mp} 194-195^{\circ},[\alpha]_{\mathrm{D}}^{28}+132^{\circ}(c=0.23)$. ORD data of III $(c=0.017$, DMSO): $[\alpha]_{580}^{22}+118^{\circ},[\alpha]_{550}^{22}+188^{\circ},[\alpha]_{500}^{22}+200^{\circ},[\alpha]_{450}^{22}+306^{\circ},[\alpha]_{500}^{22}+435^{\circ},[\alpha]_{550}^{22}+741^{\circ},[\alpha]_{825}^{22}+1494^{\circ} . \mathrm{M}^{+}:$ $m / e 588\left(\mathrm{C}_{31} \mathrm{H}_{32} \mathrm{~N}_{4} \mathrm{O}_{8}, 588.2220\right)$.

The analytical sample was identical with the authentic sample of tryptoquivaline acetate provided by G. Büchi by mixed melting point, and comparisons of thin-layer chromatograms using $\mathrm{C}_{6} \mathrm{H}_{6}$-acetone (10:1) and $\mathrm{C}_{6} \mathrm{H}_{6}-\mathrm{EtOH}(10: 1)$ as the developing solvents and IR spectra $(\mathrm{KBr})$.

De-acetylation of Tryptoquivaline C (FTC) with Alkali-A solution of FTC (200 mg) and $\mathrm{KOH}(30 \mathrm{mg})$ in $\mathrm{MeOH}(30 \mathrm{ml})$ was refluxed for $30 \mathrm{~min}$. The reaction solution was diluted with water $(130 \mathrm{ml})$, neutralized with $10 \% \mathrm{HCl}$ under ice-cooling, and extracted with ether. After evaporation of solvent, a product was obtained as a colourless resinous residue which afforded a single spot on thin-layer chromatogram (TLC) using $\mathrm{C}_{6} \mathrm{H}_{6}$-acetone (5: 1 ).

The product which had levo-optical rotation gave an acetate (IV) on acetylation with $\mathrm{Ac}_{2} \mathrm{O}(0.75 \mathrm{ml})$ and pyridine $(1.50 \mathrm{ml})$. After purification with silica gel TLC using $\mathrm{C}_{6} \mathrm{H}_{6}$-acetone $(4: 1)$, the analytical sample of acetate was obtained as colourless amorphous $(80 \mathrm{mg}$ ) which gave a single spot on a TLC-plate, $[\alpha]_{\mathrm{D}}^{24.5}-199^{\circ}(c=0.18), \mathrm{M}^{+}:$m/e $588\left(\mathrm{C}_{31} \mathrm{H}_{32} \mathrm{~N}_{4} \mathrm{O}_{8}, 588.2220\right)$, IR: $v_{\text {max }}^{\mathrm{cHCl}} \mathrm{cm}^{-1}, 1794,1737$ (shoulder), 1732, 1677, 1596. UV: $\lambda_{\max }^{\text {Meor }} \mathrm{nm}(\varepsilon), 228$ (36800), 233 (shoulder, 35300), 268 (shoulder, 13600), 279 (shoulder, 12100), 305 (shoulder, 4100), 318 (shoulder, 2900). PMR: $\delta(\mathrm{ppm}), 0.96(3 \mathrm{H}$, doublet, $J=6 \mathrm{~Hz}), 1.16(3 \mathrm{H}$, doublet, $J=6), 1.48$ ( $3 \mathrm{H}$, singlet), 1.54 ( $3 \mathrm{H}$, singlet), 2.17 ( $3 \mathrm{H}$, singlet), 2.20 ( $3 \mathrm{H}$, singlet), 2.46 (1H, multiplet), $2.70\left(1 \mathrm{H}\right.$, doublets of doublet, $\left.J_{1}=12, J_{2}=10\right), 3.37\left(1 \mathrm{H}\right.$, doublets of doublet, $\left.J_{1}=12, J_{2}=10\right), 5.25(1 \mathrm{H}$, singlet), $5.65(1 \mathrm{H}$, doublet, $J=11), 5.88\left(1 \mathrm{H}\right.$, broad triplet, $\left.J_{1}=J_{2}=10\right), 7.30-7.87(6 \mathrm{H}$, multiplet), 8.03 $(1 \mathrm{H}$, broad doublet, $J=7), 8.31(1 \mathrm{H}$, broad doublet, $J=8)$. ORD data of IV $(c=0.039$, DMSO $):[\alpha]_{589}^{21}-205^{\circ}$, $[\alpha]_{550}^{21}-333^{\circ},[\alpha]_{500}^{21}-359^{\circ},[\alpha]_{450}^{21}-513^{\circ},[\alpha]_{400}^{21}-872^{\circ},[\alpha]_{350}^{21}-1641^{\circ},[\alpha]_{323}^{21}-3949^{\circ}$.

$\mathrm{CrO}_{3}$-Oxidation of Tryptoquivaline $\mathbf{C}$ (FTC) A solution of $\mathrm{CrO}_{3}(300 \mathrm{mg})$ in water $(5.0 \mathrm{ml})$ was added dropwise to a solution of FTC $(300 \mathrm{mg})$ in AcOH $(90 \mathrm{ml})$ under ice-cooling. The flask was rinsed with additional $5 \mathrm{ml}$ of water and the washings was added to the reaction mixture. The total mixture was stirred continuously for $30 \mathrm{~min}$ under ice-cooling, diluted with water and extracted with ether repeatedly. On evaporation of solvent in vacuo, a product mixture was obtained as a pale yellow resinous residue. The product mixture was chromatographed on silica gel $(30 \mathrm{~g})$ using $\mathrm{C}_{6} \mathrm{H}_{6}, \mathrm{C}_{6} \mathrm{H}_{6}$-acetone (50:1) and (30:1). 
Colourless solid (compound B) was obtained from $\mathrm{C}_{6} \mathrm{H}_{6}$ fraction which was further crystallized from $\mathrm{MeOH}$ to obtain colourless prisms $(97 \mathrm{mg}), \mathrm{mp} 207-208.5^{\circ},[\alpha]_{\mathrm{D}}^{35.5}+162^{\circ}(c=0.14)$. Anal. Calcd. for $\mathrm{C}_{29} \mathrm{H}_{28} \mathrm{~N}_{4} \mathrm{O}_{9}$, $\mathrm{C}, 60.41 ; \mathrm{H}, 4.90 ; \mathrm{N}, 9.72$. Found: $\mathrm{C}, 60.13 ; \mathrm{H}, 4.82 ; \mathrm{N}, 9.61 . \quad \mathrm{M}^{+}:$m/e $576.1857\left(\mathrm{C}_{29} \mathrm{H}_{28} \mathrm{~N}_{4} \mathrm{O}_{9}, 576.1856\right)$. IR: $v_{\max }^{\mathrm{CC1}} \mathrm{cm}^{-1}, 1803$ (shoulder), 1792, 1735 (shoulder), 1730, 1715, 1693, 1600 . UV: $\lambda_{\max }^{\mathrm{EtoH}} \mathrm{nm}(\varepsilon), 228(44400)$, 235 (shoulder, 37600), 270 (10100), 280 (shoulder, 8500), 307.5 (3400), 320 (shoulder, 2600).

From the $\mathrm{C}_{6} \mathrm{H}_{6}$-acetone (30:1) fractions, another product (compound A) was obtained by recrystallization from $\mathrm{MeOH}$ as colourless needles $(22 \mathrm{mg}), \mathrm{mp} 160-162^{\circ},[\alpha]_{\mathrm{D}}^{28}+228^{\circ}(c=0.13)$, Molecular ion at $m / e 461.1583$ $\left(\mathrm{C}_{25} \mathrm{H}_{23} \mathrm{~N}_{3} \mathrm{O}_{6}, 461.1587\right)$. MS: $m / e(\%), 461\left(6, \mathrm{M}^{+}\right), 419\left(7.5, \mathrm{M}^{+}-42\right), 404\left(30, \mathrm{M}^{+}-57\right), 403\left(100, \mathrm{M}^{+}-58\right)$, $348(30), 201(11), 146(8)$. IR: $v_{\max }^{\mathrm{KBr}} \mathrm{cm}^{-1}, 3440,1793,1755$ (shoulder), 1735, 1685, 1620, 1601 . UV: $\lambda_{\max }^{\mathrm{MeOH}} \mathrm{nm}$ $(\varepsilon), 225.5(44000), 260$ (10700), 268 (11000), 280 (shoulder, 8400), 307 (shoulder, 4500), 318 (shoulder, 3400 ). PMR: $\delta(\mathrm{ppm}), 1.07(3 \mathrm{H}$, doublet, $J=7), 1.19(3 \mathrm{H}$, doublet, $J=7), 2.15(3 \mathrm{H}$, singlet), $2.52(1 \mathrm{H}$, multiplet), $2.67\left(1 \mathrm{H}\right.$, doublets of doublet, $\left.J_{1}=14, J_{2}=9\right), 3.51\left(1 \mathrm{H}\right.$, doublets of doublet, $\left.J_{1}=14, J_{2}=9\right), 5.56(1 \mathrm{H}$, doublet, $J=9), 5.79\left(1 \mathrm{H}\right.$, broad triplet, $\left.J_{1}=J_{2}=9\right), 7.04-7.80(7 \mathrm{H}$, multiplet), $8.32(1 \mathrm{H}$, broad doublet, $J=8), 9.07$ (1H, broad singlet, disappeared with $\mathrm{D}_{2} \mathrm{O}$ addition).

Acetylation of Compound $\mathrm{A}$ - A solution of compound A (22 mg) in $\mathrm{Ac}_{2} \mathrm{O}(0.5 \mathrm{ml})$ and pyridine (1.0 ml) was allowed to stand at room temperature overnight. Crude acetate was obtained as colourless amorphous $(19 \mathrm{mg})$, which was purified with silica gel thin-layer plates using $\mathrm{C}_{6} \mathrm{H}_{6}-\mathrm{EtOH}(10: 1)$ as a developing solvent. Crystallized from aq. MeOH as colourless prisms mp 134-137 $, \mathrm{IR}: \nu_{\max }^{\mathrm{CHCl}_{3}} \mathrm{~cm}^{-1}, 1800,1790$ (shoulder), 1725, 1690 (shoulder), 1685, 1600. UV: $\lambda_{\max }^{\mathrm{EtoH}} \mathrm{nm}(\varepsilon), 228$ (50300), 235 (shoulder, 43600), 272 (10900), 281 (shoulder, 10100), 307 (5000), 319 (3800). PMR: $\delta(\mathrm{ppm}), 1.01(3 \mathrm{H}$, doublet, $J=7), 1.13(3 \mathrm{H}$, doublet, $J=7), 2.07$ ( $3 \mathrm{H}$, singlet), 2.57 ( $1 \mathrm{H}$, multiplet), 2.65 ( $1 \mathrm{H}$, doublets of doublet, $J_{1}=13, J_{2}=10$ ), 2.68 (3H, singlet), 3.42 $\left(1 \mathrm{H}\right.$, doublets of doublet, $\left.J_{1}=13, J_{2}=10\right), 5.47(1 \mathrm{H}$, doublet, $J=9), 5.69\left(1 \mathrm{H}\right.$, triplet, $\left.J_{1}=J_{2}=10\right), 7.18-7.76$ $(6 \mathrm{H}$, multiplet), $8.26(1 \mathrm{H}$, doublet, $J=8), 8.32(1 \mathrm{H}$, doublet, $J=7)$.

Acetylation of Tryptoquivaline D (FTD)—A solution of FTD $(62 \mathrm{mg})$ in $\mathrm{Ac}_{2} \mathrm{O}(0.5 \mathrm{ml})$ and $\mathrm{AcOH}(0.5 \mathrm{ml})$ was allowed to stand at room temperature overnight, diluted with water and extracted with ether. After purification with silica gel thin-layer plates using $\mathrm{C}_{6} \mathrm{H}_{6}$-acetone (5: 1), FTD acetate was obtained as colourless prisms (27 mg) from MeOH, mp $192-195^{\circ}$ (dec.). Anal. Calcd. for $\mathrm{C}_{30} \mathrm{H}_{30} \mathrm{~N}_{4} \mathrm{O}_{8} \cdot 1 / 2 \mathrm{H}_{2} \mathrm{O}\left(574.2063+1 / 2 \mathrm{H}_{2} \mathrm{O}\right)$ $\mathrm{C}, 61.75 ; \mathrm{H}, 5.35 ; \mathrm{N}, 9.60$. Found: $\mathrm{C}, 61.91 ; \mathrm{H}, 5.26 ; \mathrm{N}, 9.52 . \quad$ IR: $\nu_{\max }^{\mathrm{CHOl}_{3}} \mathrm{~cm}^{-1}, 1798,1738$ (shoulder), 1732 , $1689,1608,1600$. UV: $\lambda_{\max }^{\text {Meor }} \mathrm{nm}(\varepsilon), 228(36600), 233$ (shoulder, 35500), 258 (shoulder, 15900), 268 (shoulder, 12300), 281 (shoulder, 10200), 306.5 (3600), 320 (shoulder, 2700). PMR: $\delta$ (ppm), 1.01 (3H, doublet, $J=7$ ), $1.15(3 \mathrm{H}$, doublet, $J=7), 1.49$ ( $3 \mathrm{H}$, doublet, $J=7), 2.15(3 \mathrm{H}$, singlet), 2.38 (3H, singlet), 2.53 (1H, multiplet), $2.96\left(1 \mathrm{H}\right.$, doublets of doublet, $\left.J_{1}=13, J_{2}=10\right), 3.23\left(1 \mathrm{H}\right.$, doublets of doublet, $\left.J_{1}=13, J_{2}=10\right), 4.54(1 \mathrm{H}$, quartet, $\left.J_{1}=J_{2}=J_{3}=7\right), 5.33\left(1 \mathrm{H}\right.$, singlet), $5.50(1 \mathrm{H}$, doublet, $J=9), 5.69\left(1 \mathrm{H}\right.$, triplet, $\left.J_{1}=J_{2}=10\right), 7.08$ $7.85(7 \mathrm{H}$, multiplet), $8.06(1 \mathrm{H}$, doublet, $J=8)$.

$\mathrm{CrO}_{3}$-Oxidation of Tryptoquivaline $\mathrm{D}$ (FTD)_-A solution of $\mathrm{CrO}_{3}(150 \mathrm{mg})$ in water $(2.0 \mathrm{ml})$ was added dropwise to a solution of FTD $(150 \mathrm{mg})$ in $\mathrm{AcOH}(27 \mathrm{ml})$ under ice-cooling. The flask was rinsed with additional $1 \mathrm{ml}$ of water and the washings was added to the reaction mixture. The product mixture was obtained by a similar way to the case of FTC oxidation and was chromatographed on silica gel (4.5 g) using $\mathrm{C}_{6} \mathrm{H}_{6}, \mathrm{C}_{6} \mathrm{H}_{6}-$ acetone $(50: 1)$ and $(30: 1)$.

The $\mathrm{C}_{6} \mathrm{H}_{6}$-acetone $(30: 1)$ fraction gave on crystallization with $\mathrm{MeOH}$ a product as colourless needles $(27 \mathrm{mg})$ which was identified with the authentic sample of compound $\mathrm{A}$ by mixed fusion $\left(\mathrm{mp} 160-162^{\circ}\right)$ and comparison of thin-layer chromatograms using $\mathrm{C}_{6} \mathrm{H}_{6}-\mathrm{EtOH}(10: 1), \mathrm{C}_{6} \mathrm{H}_{6}$-acetone $(3: 1)$ and $\mathrm{CHCl}_{3}$ acetone $(15: 1)$, IR spectra $(\mathrm{KBr})$, and proton magnetic resonance spectra.

Reduction and Hydrolysis of Tryptoquivaline D (FTD)__ Zinc powder $(6.0 \mathrm{~g})$ was added gradually to a solution of FTD $(600 \mathrm{mg})$ in $\mathrm{AcOH}(100 \mathrm{ml})$ under ice-cooling. The total suspension was stirred for $200 \mathrm{~min}$ at room temperature and filtered to remove zinc powder. A residue which was obtained on evaporation of the filtrate in vacuo was solved with $\mathrm{CHCl}_{3}$ at room temperature to remove $\mathrm{CHCl}_{3}$-insoluble portion. After evaporation of solvent in vacuo, $\mathrm{CHCl}_{3}$-soluble portion was obtained as colourless amorphous which afforded almost a single spot on TLC using $\mathrm{C}_{6} \mathrm{H}_{6}-$ acetone $(3: 1)$. Colourless prisms (from $\mathrm{CHCl}_{3}-\mathrm{MeOH}$ ), $\mathrm{mp} 233-236^{\circ}$ (dec.), $[\alpha]_{\mathrm{D}}^{31}+124^{\circ}(c=0.11)$. Anal. Calcd. for $\mathrm{C}_{26} \mathrm{H}_{26} \mathrm{~N}_{4} \mathrm{O}_{4} \cdot \mathrm{H}_{2} \mathrm{O}\left(458.1954+\mathrm{H}_{2} \mathrm{O}\right) \mathrm{C}, 65.53 ; \mathrm{H}, 5.92 ; \mathrm{N}, 11.76$. Found: $\mathrm{C}, 65.33 ; \mathrm{H}, 5.55 ; \mathrm{N}, 11.64 . \quad \mathrm{M}^{+}: m / e$ 458. IR: $v_{\max }^{\mathrm{KBr}} \mathrm{cm}^{-1}, 3400,1790,1695,1675,1605$. UV: $\lambda_{\max }^{\mathrm{EtOH}}$ $\mathrm{nm}(\varepsilon), 226.5$ (43100), 231 (shoulder, 40000), 253 (shoulder, 15700), 264 (shoulder, 12300), 275 (shoulder, 9500), 294 (shoulder, 3500), $308(3600), 320(2900) . \quad \lambda_{\max }^{\mathrm{EtOH}+\mathrm{HCl}} \mathrm{nm}(\varepsilon), 228.5(41100), 231$ (shoulder, 41000), 253 (shoulder, 16800), 275 (shoulder, 8800), 309 (3600), 320.5 (2200). PMR: $\delta(\mathrm{ppm}), 1.14(6 \mathrm{H}$, doublet, $J=6), 1.58(3 \mathrm{H}$, doublet, $J=7), 2.34\left(1 \mathrm{H}\right.$, multiplet), $2.84(2 \mathrm{H}$, doublet, $J=7), 2.95\left(1 \mathrm{H}\right.$, broad peak, disappeared with $\mathrm{D}_{2} \mathrm{O}$ addition), $3.07\left(2 \mathrm{H}\right.$, broad doublet like), $4.19\left(1 \mathrm{H}\right.$, quartet, $\left.J_{1}=J_{2}=J_{3}=7\right), 5.33\left(1 \mathrm{H}\right.$, triplet, $\left.J_{1}=J_{2}=10\right)$, $5.40(1 \mathrm{H}$, singlet), $7.11-7.87(7 \mathrm{H}$, multiplet), $8.24(1 \mathrm{H}$, doublet, $J=8)$. The product $(0.5-1.0 \mathrm{mg})$ was soluble in $1 \mathrm{~N} \mathrm{HCl}$ solution ( 2 drops) at room temperature.

The reduction product was then hydrolyzed with $6 \mathrm{~N} \mathrm{HCl}(20 \mathrm{ml})$ on refluxing for $1 \mathrm{hr}$. After evaporation of solvent in vacuo, hydrolyzate was obtained as a pale yellow residue. The water soluble portion of the hydrolyzate was chromatographed on filter papers (Toyo Roshi No. $50,40 \times 40 \mathrm{~cm}, 5 \mathrm{sheets}$ ) using an upper layer of $n-\mathrm{BuOH}-\mathrm{AcOH}-\mathrm{H}_{2} \mathrm{O}(4: 1: 5)$. Extraction was carried out with water $(200 \mathrm{ml})$ under stirring 2 times for $10 \mathrm{~min}$ at room temperature. After evaporation of solvent in vacuo, a hygroscopic colourless residue 
(74 mg) which gave single spot both on TLC and paper chromatograms using ninhydrin as a detecting reagent was obtained. The product was identified with authentic $L-(+)$-alanine by comparison on TLC and paper chromatograms using an upper layer of $n-\mathrm{BuOH}-\mathrm{AcOH}-\mathrm{H}_{2} \mathrm{O}(4: 1: 5)$ and liquid chromatograms $[\mathrm{Hitachi}$ Custom Ion-Exchange Resin 2612, citrate buffer solution pH 4.25, pump pressure: $0.6 \mathrm{~kg} / \mathrm{cm}^{2}$ (buffer solution), $0.3 \mathrm{~kg} / \mathrm{cm}^{2}$ (ninhydrin solution), temperature: $58^{\circ}$, retention time: $74 \mathrm{~min}$ ], and optical rotatory dispersion curves (positive plain curves). ORD data of the product $(c=2.02,6 \mathrm{~N} \mathrm{HCl}):[\alpha]_{589}^{23.5}+6.7^{\circ},[\alpha]_{550}^{23.5}+7.2^{\circ}$, $[\alpha]_{500}^{23.5}+9.7^{\circ},[\alpha]_{450}^{23.5}+12.9^{\circ},[\alpha]_{400}^{28.5}+19.3^{\circ},[\alpha]_{350}^{23.5}+31.2^{\circ}$. ORD data of authentic $L-(+)$-alanine $(c=0.16$, $6 \mathrm{~N} \mathrm{HCl}) ;[\alpha]_{589}^{23}+13.9^{\circ},[\alpha]_{550}^{23}+20.3^{\circ},[\alpha]_{500}^{23}+31.6^{\circ},[\alpha]_{450}^{23}+35.4^{\circ},[\alpha]_{400}^{23}+45.6^{\circ},[\alpha]_{850}^{23}+75.9^{\circ}$.

Acknowledgement The authors are indebted to Professor G. Büchi for a gift of tryptoquivaline acetate. Thanks are also due to Miss M. Sumita for technical assistance, Miss K. Takizawa for the NMR spectra, Miss $\mathrm{H}$. Ohida for elementary analysis and Miss J. Nakajima for mass spectra. 